\title{
Compliance or management: The benefits that small business owners gain from frequently sourcing accounting services
}

\begin{tabular}{|c|c|}
\hline \multicolumn{2}{|c|}{$\begin{array}{l}\text { Authors: } \\
\text { Adele Oosthuizen }{ }^{1} \\
\text { Jurie van Vuuren } \\
\text { Melodi Botha }{ }^{1}\end{array}$} \\
\hline \multicolumn{2}{|c|}{$\begin{array}{l}\text { Affiliations: } \\
{ }^{1} \text { Department of Business } \\
\text { Management, Faculty of } \\
\text { Economic and Management } \\
\text { Sciences, University of } \\
\text { Pretoria, Pretoria, } \\
\text { South Africa }\end{array}$} \\
\hline \multicolumn{2}{|c|}{$\begin{array}{l}\text { Corresponding author: } \\
\text { Adele Oosthuizen, } \\
\text { aoosthuizen@uj.ac.za }\end{array}$} \\
\hline \multicolumn{2}{|c|}{$\begin{array}{l}\text { Dates: } \\
\text { Received: } 23 \text { Mar. } 2020 \\
\text { Accepted: } 27 \text { May } 2020 \\
\text { Published: } 30 \text { June } 2020\end{array}$} \\
\hline \multicolumn{2}{|c|}{$\begin{array}{l}\text { How to cite this article: } \\
\text { Oosthuizen, A., Van Vuuren, J., } \\
\text { Botha, M., 2020, 'Compliance } \\
\text { or management: The benefits } \\
\text { that small business owners } \\
\text { gain from frequently } \\
\text { sourcing accounting services', } \\
\text { Southern African Journal of } \\
\text { Entrepreneurship and Small } \\
\text { Business Management 12(1), } \\
\text { a330. https://doi.org/ } \\
10.4102 / \text { sajesbm.v12i1.330 }\end{array}$} \\
\hline \multicolumn{2}{|c|}{$\begin{array}{l}\text { Copyright: } \\
\text { (C) 2020. The Authors. } \\
\text { Licensee: AOSIS. This w } \\
\text { is licensed under the } \\
\text { Creative Commons } \\
\text { Attribution License. }\end{array}$} \\
\hline \multicolumn{2}{|c|}{ Read online: } \\
\hline 回部品 & $\begin{array}{l}\text { Scan this QR } \\
\text { code with your } \\
\text { smart phone or } \\
\text { mobile device } \\
\text { to read online. }\end{array}$ \\
\hline
\end{tabular}

Background: Despite calls by scholars for small business owners (SBOs) to seek external consultation from accountants, empirical work demonstrating the relationship between the frequency of various types of services sourced and the perceived benefits obtained remains neglected.

Aim: The purpose of this article was to determine the benefits that SBOs obtain from the frequency by which they source different types of accounting services.

Setting: Survey data were collected from a sample of 422 South African SBOs. Small business owners are defined as those who own a distinct business entity with no more than 200 employees.

Methods: The study followed a quantitative research approach. Structural equation modelling was used to test the hypotheses.

Results: Overall, the study found that the frequency by which different types of accounting services are sourced influences SBOs' perceptions of the levels of management versus compliance benefits obtained. Results show that SBOs that frequently source the service of submitting income tax returns perceive the relationship with their accountant to provide significant compliance benefits. Small and medium enterprises (SMEs) that source tax planning services and routine accounting services from their accounting practitioners experience significant compliance and management benefits. Results confirm the notion that no significant benefit are gained from yearend accounting services, such as the preparation and audit of annual financial statements.

Conclusions: The study advises SBOs not to limit their perceptions regarding the role of an accountant to that of a compliance officer. The article suggests that by sourcing advisory services more frequently, SMEs could overcome the difficulties associated with an internal lack of financial skills.

Keywords: resource-based view; small business accounting; small accounting practitioners; accounting services; advisory services.

\section{Introduction}

Small and medium enterprises (SMEs) play a crucial role in any economy as a key generator of employment and income worldwide (Davidsson 2018). However, the majority of SMEs in emerging economies cannot compete effectively because of their internal resource (i.e. human capital) gap (De Bruyckere et al. 2018; Kamyabi \& Devi 2011). Furthermore, whilst finance is the lifeblood of a business (Oseifuah \& Manda 2017), financial literacy and financial management skills pose a significant challenge to the growth of SMEs (Fraser, Bhaumik \& Wright 2015), particularly in South Africa (Mamabolo, Kerrin \& Kele 2017).

In this regard, accountants are known to be the most commonly used small business advisors. However, previous studies have reported mixed results regarding the economic benefits that SMEs obtain from this relationship (Collis 2012; Halabi, Barret \& Dyat 2010). Scholars have identified a multitude of inter-related factors affecting the relationship between SMEs and small accounting practitioners (SAPs) (Blomkvist, Johansson \& Malmström 2016; Carey \& Tanewski 2016). Amongst these, the frequency by which SMEs source different types of accounting services has been suggested as important (Kirby \& King 1997; Marriott \& Marriott 2000; Nandan 2010). It is argued that where internal financial management skills are limited, SMEs should source a range of different services from their external accounting practitioner to secure both compliance and management 
benefits (Blackburn \& Jarvis 2010; Sarens et al. 2015). Yet, the link between the frequency by which these services are sought and the potential benefits is not clear. This article, therefore, develops and tests a model to establish this link.

Proponents of the resource-based view (RBV) suggest that the resources of a business are fundamental drivers of both performance and competitive advantage (Łobacz \& Głodek 2015:489). It is argued that smaller firms are more vulnerable than their larger counterparts because of lack of necessary resources and capability for survival and growth (Kellermanns et al. 2016). Because of these mentioned resource gaps, SMEs are often forced to optimise the use of their external resources to lessen costs and create an advantage. Accountants are educated in analytical techniques and are expected to continuously develop their knowledge base and technical skills to maintain their expertise (Dyer \& Ross 2007). According to Prauliņš and Bratka (2014:98), SMEs should use an external accountant for advice which directly affects performance. This advice could include help on how to generate higher revenues, or how to improve management control, regulatory compliance, performance reviews, the business' financial structure or financial planning. Similarly, Han and Benson (2010) concluded that assistance and advice are valuable for small business owners (SBOs) and entrepreneurs to compensate for their lack of human capital and thus to facilitate overcoming possible problems in managing their businesses. Research evidence suggests that by seeking external advice, SBOs could enhance their learning and capabilities for future decision-making (Sian \& Roberts 2009). Small accounting practitioners are therefore able to supply a range of competencies that could support SMEs' intangible resources and, hence, their competitive advantage (Barbera \& Hasso 2013; Kellermanns et al. 2016).

Drawing on the RBV, this article posits that the role of SAPs is to assist SBOs by offering services that overcome the latter's lack of financial management skills as well managerial, strategic and operational know-how (Kamyabi \& Devi 2011) from which they should, in turn, derive benefits. Whilst extensive research has been conducted on the lack of resources, particularly financial resources, which SMEs receive from a supply point of view, little work has explored the cognitive resources of SBOs and how this impacts SME outcomes (Fraser et al. 2015). Despite scholars urging SBOs to seek external consultation from SAPs (Dyer \& Ross 2007; Hussain, Salia \& Karim 2018) and previous work suggesting that there exist relationships between the types of services sourced from SAPs and the benefits obtained by SBOs (Kirby \& King 1997; Marriott \& Marriott 2000; Nandan 2010), empirical evidence of these relationships is scarce and fails to provide conclusive evidence on which services offer particular benefits. Therefore, the objective of this article is to address this gap by postulating and testing a model aimed at understanding how the frequency by which SMEs source different types of accounting services influences SBOs' perceptions of the benefits they obtain from their accountants.
The results that this article contributes are threefold. Firstly, by drawing on the RBV, the article contributes to RBV theory from the perspective of SMEs and how they handle their typical internal resource, knowledge and human capital constraints. Whilst it is evident that resources are fundamental drivers of a business in terms of both performance and competitive advantage (Łobacz \& Głodek 2015), current literature fails to account for which of, and how, the various services provided by SAPs contribute from a human capital resources perspective (Bagieńska 2016; Łobacz et al. 2016). This article demonstrates which of the various services offered by SAPs to SBOs provide benefits from a compliance as well as a management perspective and, as such, which of these services are beneficial from a RBV of the firm. Secondly, from a practical perspective, by informing SBOs about the types of services they need to source from their accountants in order to overcome any internal lack of financial and management skills, this article suggests ways for SBOs to secure benefits necessary for the survival and future growth of their businesses. For example, it is recommended that SBOs that lack the required financial management skills to run and grow their businesses should consider sourcing additional services from their SAPs. Finally, from a pedagogical and policy perspective, educators, training providers, banks and business coaches can use these results to encourage SBOs to build a strong relationship with their SAPs and motivate them to source the right combination of services to secure long-term performance and economic sustainability.

\section{Theoretical foundation and hypotheses development Types of services provided by small accounting
practitioners}

Literature has broadly categorised accounting services into two segments: (1) traditional accounting services and (2) advisory services (Blackburn \& Jarvis 2010; Carey 2008, 2015; Collis 2012; Devi \& Samujh 2010).

Traditional accounting services are those services that are offered by the external accountant to prepare accounting information, which is either considered necessary to manage a business properly or mandatory for compliance purposes (Everaert, Sarens \& Rommel 2007). Accounting services of this nature can be classified as bookkeeping, monthly reporting, year-end accounting services consisting of statutory and compliance services, as well as the completion and submission of tax returns. Everaert, Sarens and Rommel (2010) further refined the classification of traditional accounting tasks as routine and non-routine tasks. The former are those tasks that require relatively straightforward or standardised procedures. They need less judgement on the part of the accountant (Everaert et al. 2010; Oosthuizen 2018) and typically include record-keeping and monthly reporting. On the contrary, non-routine tasks are more complex and require more judgement from the accountant (Everaert et al. 2010), such as tax compliance and year-end reporting 
procedures. In line with these classifications, this article analyses the types of services, according to the frequency by which they are sourced, from the accountant. It specifically investigates the relationship between the frequency of types of services sourced (routine and non-routine traditional accounting services) and the perception of benefits received from the said sourced services. Advisory services in this study refer to 'advice supporting the information needs of management in the operation of the business' (Carey 2015:168).

According to Bennett and Robson (2000), the advisory services offered to SBOs are closely linked to the goals, objectives and strategic decisions of the business and usually exclude the provision of basic information.

Considering these definitions, advisory services in the context of this article refer to the services offered by SAPs to assist SBOs in managing the liquidity, profitability and growth of their businesses. These exclude all bookkeeping, annual financial reporting and compliance-related services.

\section{Relationship between the frequency by which small business owners source traditional year- end accounting services and the benefits obtained}

This article proposes that there is a relationship between the types and frequency of services sourced from the SAP and the benefits that SBOs obtain from this relationship. Traditionally, the role of the external accountant was viewed as only to provide monitoring and compliance services to meet audit and tax-related requirements (Blackburn, Tanewski \& Carey 2010b; Carey 2008). Although the accounting profession has witnessed a shift towards the notion that SAPs are increasingly being used for business advisory and support services (Bennett 2007; Dyer \& Ross 2007), evidence suggests that SAPs are still overwhelmingly used to provide the traditional accounting services (Collis \& Jarvis 2000, 2002; Doving \& Gooderham 2008). Devi and Sumujh (2010) reported that SAPs spend $60 \%$ of their time on compliance work, consisting mainly of tax filing, compiling annual financial statements (AFS), auditing and secretarial services.

According to Marriott and Marriott (2000), the demand for these traditional year-end accounting services is still mainly driven by regulatory requirements. As a result, these services are often referred to as a 'distress purchase' (Blackburn \& Jarvis 2010), and their usefulness is questioned. Collis and Jarvis (2000) reported that SBOs perceived their statutory accounts to be useful only if they are viewed in conjunction with other sources of information, to confirm and verify results, or to establish directors' emoluments. These findings were supported by Marriott and Marriott (2000), who stated that SBOs perceive statutory accounts to have few benefits in supporting decision-making and control. In addition, Kirby and King (1997) suggested that when only basic bookkeeping and compliance services are sourced, clients do not obtain appropriate or adequate information to support planning, decision-making and control. These results are however not surprising in that the purpose of statutory accounts is to provide information to a wide range of users, normally external to the organisation (Halabi et al. 2010; Sian \& Roberts 2009).

It is therefore expected that year-end financial reporting services are intended to primarily provide small businesses with tax and audit compliance benefits (Collis \& Jarvis 2000; Everaert et al. 2007; Halabi et al. 2010) but very few management benefits (Marriott \& Marriott 2000). Nawaz (2012) found that merely one-third of SBOs use the financial information prepared by accountants for internal decisionmaking purposes. The reasons for these minimal decisionmaking benefits are the following: (1) year-end financial reports were never intended for internal decision-making purposes. For example, where financial statements were produced explicitly for tax purposes, SBOs believed that they had limited use because the figures were deliberately kept low to reduce their tax liability (Halabi et al. 2010). (2) Financial reporting standards were developed for larger organisations, from the viewpoint that capital markets are the most important user group. Such standards are therefore not always appropriate for medium and smaller entities as the output is aimed at a different set of users with different needs. The existence of 'unique SME factors, such as close-knit agency relationships and a tendency to aim for survival and stability over profit maximisation and growth' (Sian \& Roberts 2009), is not taken into consideration. In addition, because of their complexity, owners often find it hard to follow accounting reports prepared under the generally accepted accounting rules (Kirby \& King 1997). (3) Financial reports are usually outdated by the time they are prepared and presented to SBOs (Sian \& Roberts 2009). The annual statements were mainly used to compare income and costs with prior periods or for a confirmatory function. If such an information is to be useful for decision-making and control, it must be timely and produced more frequently (Everaert et al. 2007). (4) McChlery, Godfrey and Meechan (2005) found that $72.6 \%$ of respondents in their study felt strongly that the AFS are not useful because they merely replicate their own internal accounts.

Although the majority of research findings point to the fact that small businesses derive very little or no management benefit from these traditional service offerings, some studies have nonetheless indicated several possible benefits: (1) non-compliance, especially tax compliance, may subject the SBO to severe emotional stress (Amoako 2013). Owners are responsible for ensuring that their companies remain compliant with relevant legislations (Carey 2008; Collis 2012; Nandan 2010). Non-compliance may further result in penalties and fines, putting the organisation under financial pressure (Barnardt 2016; Wolmarans \& Meintjes 2015). (2) Obtaining contracts from larger companies or government, specifically in South Africa, requires organisations to comply with legislation such as possessing tax clearance, submitting 
up-to-date financial statements to the Companies and Intellectual Property Commission (CIPC) and complying with Broad Based Black Economic Empowerment (BBBEE) codes (Barnardt 2016). Non-compliance may, therefore, result in a small business not being awarded lucrative contracts. (3) The value of a business is typically determined on the basis of evidence obtained from the financial records and financial statements of the organisation (Nieman \& Nieuwenhuizen 2014). Inaccurate or incomplete financial records may therefore adversely affect the value of the business. (4) Compliance further signals a well-controlled environment, resulting in financiers being less willing to grant funding to entrepreneurs who do not adhere to compliance requirements (Agyei-Mensah 2011; Amoako 2013). (5) Collis (2012) has suggested that comprehensive financial reporting and insightful financial analysis lead to improved financial and operational control and that this in itself could significantly increase the chances of a small enterprise prospering through growth. Indeed, a comparative study conducted on six countries, including South Africa, established that by sourcing traditional services from accountants, small businesses are provided with a 'good deal of generalist advice' (Schizas, Jarvis \& Daskalakis 2012). Burke and Jarratt (2004) reported SAPs to be a good source of operational advice but not to be a high-value source of strategic advice. In addition, Niemi et al. (2016) stated that small businesses which experience financial distress are more likely to utilise external accountants for voluntary audit services in order to obtain management advice. (6) The research by Allee and Yohn (2009) and Collis and Jarvis (2002) indicated that audited financial statements play an agency role in the relationship between small businesses and their banks, resulting in improved access to credit and reduced interest rates.

As stated, previous studies have established a relationship between routine and non-routine transactions and frequency of accounting tasks (i.e. whether the task is performed daily, weekly, monthly or annually) (Everaert et al. 2010; Kamyabi \& Devi 2011). Small and medium enterprises typically source traditional accounting services, such as completing tax returns, monthly reporting and audits or independent reviews, on a monthly or on an annual basis. Based on the arguments presented, a commonly accepted view is that SBOs mainly derive compliance benefits, but very few management benefits, when sourcing traditional accounting services from their accountants. The evidence, however, is not conclusive regarding the benefits obtained from such accounting services. This article will, therefore, test the following hypotheses:

H1: There is a positive relationship between the frequency of routine accounting services sourced by $\mathrm{SBO}$ s and their perceptions of compliance benefits received from the accounting practitioner

$\mathrm{H} 2$ : There is a positive relationship between the frequency of routine accounting services sourced by SBOs and their perceptions of management benefits received from the accounting practitioner.
H3: There is a positive relationship between the frequency of non-routine accounting services sourced by SBOs and their perceptions of compliance benefits received from the accounting practitioner.

H4: There is a positive relationship between the frequency of non-routine accounting services sourced by SBOs and their perceptions of management benefits received from the accounting practitioner.

\section{Relationship between the frequency of sourcing advisory services and benefits obtained}

The role of accountants has developed over time from the stereotypical 'bean counter' image typically associated with bookkeepers into a role that comprises a much wider range of duties (Jones \& Abraham 2007). It has been argued that a general shift in the accounting role has taken place - from mere information provision to extended information facilitation - (Burns \& Scapens 2000) and that this has resulted in the expectation that SAPs should progressively move towards being business advisors (Jones \& Abraham 2007). Accordingly, these types of practices have expanded their range of services to include different types of advisory services (Devi \& Samujh 2010:1).

This shift has sparked a surge in research studies, investigating the advisory role of SAPs. These studies have suggested that if small businesses want to derive benefits from their external accountants, they should source both compliance and advisory services, because compliance services on their own provide limited benefit (Bagieńska 2016; Bennett \& Robson 2010; Blackburn et al. 2010b:30; Devi \& Samujh 2010; Han \& Benson 2010; Łobacz \& Głodek 2015; Łobacz et al. 2016; Nandan 2010).

Consequently, it is now commonly accepted that SBOs that regularly source advisory services from their accountants would obtain more benefits from the relationship than those who do not source (Blackburn, Carey \& Tanewski 2010a; Carey 2015; Devi \& Sumujh 2010).

Studies performed by Bennett and Robson (2010) and Carey (2015) have hypothesised a positive relationship between the sourcing of business advice and financial performance. Nevertheless, the findings of these studies are mixed and inconclusive, leaving room for further investigation of the benefits derived from advisory services. Although there has been an increase in the advisory services offered by accountants, SBOs still do not use external accountants for management accounting and/or advisory services to such an extent that they are provided with all the benefits required (Blackburn et al. 2010a:4; Ciccotosto, Nandan \& Smorfitt 2008; Marriott \& Marriott 2000). Research has further indicated that there is a reluctance amongst SBOs to actively seek business advice (Blackburn \& Jarvis 2010:18,19; Nandan 2010).

An international comparative study by Schizas et al. (2012:24), which investigated the relationship between SBOs and their advisors, found that in developed countries such as Canada, 
Italy and the United Kingdom, SAPs were perceived to command a very broad range of expertise, encompassing not only traditional competences (such as financial management or tax) but also less traditional ones (such as regulation, advisory and IT operations). Unexpectedly, that paper discovered that in emerging economies, specifically in China and South Africa, the views regarding the role of accountants were much narrower, with SBOs acknowledging just the core skill set of the accountants. The report further indicated that it is possible for practitioners to build a reputation as business experts and, by implication, to survive without relying on compliance work. In South Africa, it is therefore crucial that SAPs focus on promoting advisory services to their clients. Professional bodies should also make a deliberate effort to improve the skillsets of their members. In contrast with traditional accounting services, advisory services are classified as non-routine services, that is, they are sourced on an ad hoc basis (Everaert et al. 2007). The frequency by which SMEs source these types of services may therefore have an impact on the benefits obtained.

Consequently, it is proposed that SBOs that more frequently source advisory services from their external accountants would perceive their relationship as being more beneficial than those who do not source. Evidence on the benefits obtained from advisory services is nonetheless contradictory and inconclusive, and this article will therefore test the following hypotheses (see Figure 1):

H5: There is a positive relationship between the frequency of advisory services sourced by SBOs and their perceptions of compliance benefits received from the accounting practitioner.

H6: There is a positive relationship between the frequency of advisory services sourced by SBOs and their perceptions of management benefits received from the accounting practitioner.

\section{Methods and sampling procedure}

This article addressed the research problem from a positivistic paradigm and used a cross-sectional, ex post facto design. The unit of analysis in the study comprised South African SBOs. The population consists of any person who owns a separate and distinct business entity, including a co-operative enterprise or a non-governmental organisation located in

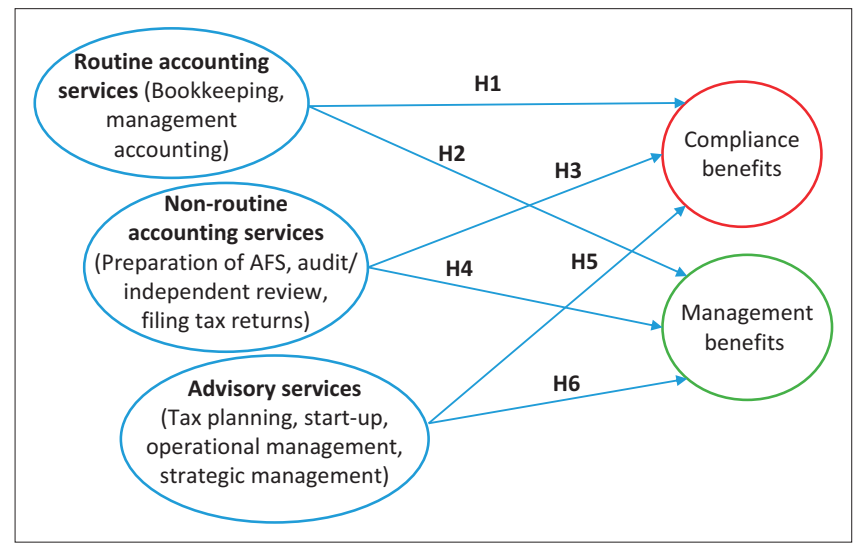

AFS, annual financial statements.

FIGURE 1: Hypothesised model.
South Africa with less than 200 employees. Because of the practical restrictions associated with probability sampling, the study used a convenient sampling method to collect data.

The survey was administered using both electronic and paper-based questionnaires The survey was manually administered to SBOs at two local (Gauteng) and one national small business network events. The electronic questionnaire was emailed to the database of approximately 6000 South African SBOs. A total of 444 surveys were conducted, of which only 422 responses were usable.

The sample population comprised $32.2 \%$ women and $67.8 \%$ men. The respondents are considered well educated, with the majority $(73.5 \%)$ of them having a tertiary or professional qualification. Just over $15 \%(17.3 \%)$ had a national senior certificate. The majority of respondents $(70.7 \%)$ considered themselves to have a reasonable to very good knowledge and understanding of accounting. Of the respondents, 10\% stated to have an expert knowledge and understanding of accounting. Surprisingly, only $19.2 \%$ of respondents considered themselves to have basic or no knowledge and understanding of accounting. The SMEs represented in the study consisted of $43.6 \%$ micro-enterprises - in other words, enterprises with five or fewer employees. Forty-five per cent could be classified as small or very small enterprises, with more than five but up to 50 employees, whilst $11.6 \%$ were classified as medium enterprises, with between 50 and 200 employees. The vast majority (96\%) of them could be classified as established businesses operating for longer than 3.5 years. Fifty-three per cent had been in operation for longer than 15 years, 13.2\% had been for $12-15$ years and $16.5 \%$ had been for $7-12$ years.

\section{Measures}

Two constructs were measured in the study: the frequency by which SMEs source different accounting services and SBOs' perceptions of the benefits obtained. A list of services that SAPs offer was compiled from various literature sources (Devi \& Samujh 2010; Doving \& Gooderham 2008; Everaert et al. 2007; McChlery et al. 2005). Twelve items measured the frequency by which SMEs source various accounting services. A five-point direct rating scale was used to measure the frequency (see Table 1). Options varied from ' 1 ' representing never, ' 2 ' representing less than once a year, ' 3 ' representing once a year, ' 4 ' representing more than once a year but not monthly and ' 5 ' representing very often (monthly).

The list of benefits included in the questionnaire was obtained from literature sources as justified in the literature review. A four-point direct rating scale was used to judge perceptions of benefits, with ' 1 ' representing 'strongly agree' and ' 4 ' representing 'strongly disagree'. A list of benefits is presented in Table 2.

\section{Data analysis}

Structural equation modelling (SEM) using Amos (version 24) with maximum likelihood estimation was used to test the 
relationships between the frequencies by which SMEs source different types of accounting services and the SBOs' perceptions of benefits. Consistent with recommendations by Hair et al. (2010), SEM analysis was conducted using a twostep approach: (1) the adequacy of the measurement model was assessed and (2) the structural model was tested. As this article used newly developed scales, confirmatory factor analysis was not deemed appropriate. Thus, the reliability, validity and latent factor structure of the scales were determined using exploratory factor analysis (EFA). Principal axis factoring (PAF) with Promax rotation was used to assess the validity of the measuring instruments as it is regarded as a more robust form of factor analysis (Beaumont 2012:5). For all relevant constructs, the Kaiser-Meyer-Olkin measure of sampling adequacy and Bartlett's test of sphericity were carried out, which indicated that EFA was appropriate. The criterion of eigenvalues $>1$ was used to determine the number of factors to be extracted. The reliability of these factors was

TABLE 1: Accounting service questionnaire items.

\begin{tabular}{|c|c|}
\hline Number & Services \\
\hline 1. & Bookkeeping services \\
\hline 2. & Management accounts \\
\hline 3. & Drafting annual financial statements \\
\hline 4. & Audit or independent review of annual financial statements \\
\hline 5. & Filing VAT returns \\
\hline 6. & Filing income tax returns \\
\hline 7. & Tax planning and tax advisory services \\
\hline 8. & Payroll and PAYE services \\
\hline 9. & Secretarial services (CIPC and other regulatory services) \\
\hline 10. & $\begin{array}{l}\text { Advisory services relating to the start-up of a new business including } \\
\text { business plans and obtaining start-up finance }\end{array}$ \\
\hline 11. & $\begin{array}{l}\text { Advisory services relating to the operational financial management of } \\
\text { the business (such as budgeting, cash flow management and profit } \\
\text { improvement programmes) }\end{array}$ \\
\hline 12. & $\begin{array}{l}\text { Advisory services relating to strategic financial management of the } \\
\text { business (such as growth and expansion decisions, capital investment } \\
\text { decisions and acquiring additional finance) }\end{array}$ \\
\hline
\end{tabular}

VAT, Value Added Tax; PAYE, Pay-as-you-earn; CIPC, Companies and Intellectual Property Commission.

TABLE 2: Questionnaire items for measuring the perception about benefits. Number Statement

1. The services sourced from my accountant help to overcome the financial skills lacking within my business.

2. The services I source from my accountant enhance my ability in managing my business strategically.

3. The services I source from my accountant help my business to remain tax compliant.

4. The services I source from my accountant contribute to my business's compliance with relevant laws and regulations.

5. The financial information I receive from my accountant supports my business decisions.

6. The financial information I receive from my accountant is useful as an operational tool in controlling my business.

7. The financial information I obtain from my accountant is mainly prepared because it is required for external reporting to banks, creditors, SARS and the CIPC.

8. I understand the financial information I receive from my accountant.

9. The financial information obtained from my accountant is useful in managing my business.

10. Where applicable my accountant explains the financial information he or she prepared.

11. My accountant assists me in using the financial information prepared to better manage my business.

12. Overall, I would rank the relationship between my accountant and me as beneficial to my business.

CIPC, Companies and Intellectual Property Commission; SARS, South African Revenue Service. subsequently determined by using Cronbach's alpha $(\alpha)$ and a threshold value of $>0.7$ (Hair et al. 2010:125).

\section{Results}

\section{Exploratory factor analysis and reliability of the measurement model}

The underlying factor structure of the 12 items included for different types of services sourced was first assessed. Three items that had a low $(<0.4)$ or double factor loading were eliminated from the analysis. In this regard, based on EFA, the services relating to tax planning and the completion of annual tax returns were excluded because these items did not adequately load onto any factor. However, services relating to taxation are regarded as fundamental offerings by SAPs. In fact, descriptive analysis conducted in this article revealed that $95 \%$ of SBOs use these services to ensure that they remain tax compliant. These items were, therefore, treated as separate endogenous variables when performing further analysis. Although single-item constructs are not recommended, it is permissible when the construct is simple and lacks nuance and complexity (Hair et al. 2010:701). The items indicated adherence to these criteria, as their behaviour is directly observable, and each item is sufficiently different to constitute a single construct. As there were three eigenvalues greater than 1, a three-factor structure was revealed, explaining 73\% of the variance in accounting services sourced construct. Table 3 presents the EFA results, factor loadings and Cronbach's alpha for these factors.

The items loading onto factor 1 relate to routine accounting services, that is, services which are normally sourced on a monthly basis. The routine services factor demonstrated a sufficient internal consistency, with an $\alpha$ of 0.851 . The items loading onto factor 2 consist of start-up advisory services, operational advisory services and strategic advisory services. The items all relate to advisory services and have an acceptable Cronbach's alpha of 0.878 .

Two items loaded onto factor 3, both relating to year-end accounting services. The Cronbach's alpha was calculated as 0.485 , pointing to an insufficient level of internal consistency of the factor items.

TABLE 3: Pattern matrix for the frequency of different types of services sourced.

\begin{tabular}{lccc}
\hline Variable & \multicolumn{3}{c}{ Types of services factor } \\
\cline { 2 - 4 } & $\begin{array}{c}\text { Routine } \\
\text { accounting } \\
\text { services }\end{array}$ & $\begin{array}{c}\text { Advisory } \\
\text { services }\end{array}$ & $\begin{array}{c}\text { Year-end } \\
\text { accounting } \\
\text { services }\end{array}$ \\
\hline Drafting AFS & - & - & 0.731 \\
Audit/independent review & - & - & 0.427 \\
VAT returns & 0.833 & - & - \\
Payroll and PAYE & 0.724 & - & - \\
Start-up advice & - & 0.765 & - \\
Operational advice & - & 0.810 & - \\
Strategic advice & - & 0.933 & - \\
Bookkeeping & 0.797 & - & - \\
Management accounting & 0.702 & - & - \\
Cronbach's alpha & 0.851 & 0.878 & 0.485 \\
\hline
\end{tabular}

AFS, annual financial statement; PAYE, Pay-as-you-earn. 
Furthermore, the factor loading for audit and independent review services was low (0.427). The statistical tests therefore provided evidence that using these items as manifest variables to measure year-end services as a latent variable may distort the results of further analysis. Although services relating to the preparation of AFS and the audit or independent review of AFS usually are sourced on an annual basis, it is argued that they should be treated separately. The main reason is that, based on this article's EFA, SMEs hold very different expectations and perceptions about each of these services. Consequently, grouping the services together may lead to distorted findings. Thus, these services are considered as separate sub-factors of non-routine accounting services. The article has therefore identified the following latent variables to represent the frequency by which accountants source different types of services: the preparation of AFS, audit or independent review of AFS, tax planning services, the completion of annual tax returns, routine (monthly accounting services) and advisory services.

Subsequently, the underlying factor structure of the seven items included for the SBOs' perceptions of benefits obtained was assessed. A two-factor structure was revealed, which explained $77 \%$ of the variance in the construct. Table 4 presents the EFA results, factor loadings and Cronbach's alpha for these two factors: compliance benefits and management benefits. The Cronbach's alpha was 0.908 for the management benefits factor and 0.757 for the compliance benefits factor, both indicating a sufficient internal consistency reliability.

\section{Structural model and hypotheses testing}

To assess the individual relationships hypothesised in this article, the structural model was assessed to ensure adequate model fit. The structural model demonstrated a good overall fit. The $\chi^{2}$ was 1098.4, with 549 degrees of freedom. As anticipated, the hypothesis of exact fit (root mean square error of approximation [RMSEA] =0) was rejected, based on a statistically significant $p$-value of 0.000 . The minimum value of the discrepancy, $C$, divided by the degrees of freedom $(\mathrm{CMIN} / d f)$ ratio of 2.001 was well below the threshold of 3 .

A comparison of the baseline indices indicated an Adjusted Goodness of Fit Index (AGFI) of 0.844 (>0.8) and a Confirmatory Fit Index (CFI) of 0.944 (> 0.9). The RMSEA is 0.049 and, when

TABLE 4: Pattern matrix for small business owners' perceptions about benefits.

\begin{tabular}{lcc}
\hline Variable & \multicolumn{2}{c}{ Benefits factor } \\
\cline { 2 - 3 } & $\begin{array}{c}\text { Management } \\
\text { benefits }\end{array}$ & $\begin{array}{c}\text { Compliance } \\
\text { benefits }\end{array}$ \\
\hline Manage the business & 0.549 & - \\
Tax compliance & - & 0.872 \\
Legal compliance & - & 0.693 \\
Decision-making & 0.826 & - \\
Operational control and management & 0.918 & - \\
Strategic management & 0.892 & - \\
Assistance to use information & 0.782 & - \\
Cronbach's alpha & 0.908 & 0.757 \\
\hline
\end{tabular}

assessed at a $90 \%$ confidence level, it lies between 0.045 and 0.053 , all below the recommended threshold of 0.07 . In addition, the Close Fit (PCLOSE) (0.683) is also well above the threshold of 0.05 (Weston \& Gore 2006). Figure 2 illustrates the structural model, along with the statistical significance of path coefficients and adjusted $r^{2}$ scores.

Hypothesis 1 suggests that there is a positive relationship between the frequency of routine accounting services sourced by SBOs and their perceptions of the compliance benefits received from their accounting practitioner. Support for this hypothesis is evident as reported in Figure 2. Owners of SMEs that frequently source routine accounting services perceived a significant compliance benefit from the SAP $(\beta=0.129 ; p<0.1)$.

Hypothesis 2 suggests that there is a positive relationship between the frequency of routine accounting services sourced by SBOs and their perceptions of management benefits received from the accounting practitioner. Support for this hypothesis is found as SBOs that sourced routine accounting services reported a significant positive relationship with management benefits from the $\operatorname{SAP}(\beta=0.129 ; p<0.05)$.

Hypothesis 3 suggests that there is a positive relationship between the frequency of non-routine accounting services sourced by SBOs and their perceptions of compliance benefits received from the accounting practitioner. Whilst a significant relationship was not found for the two sub-factors of drafting AFS $(\beta=0.025 ; p>0.1)$ and Independent Review (IR)/audit $(\beta=0.023 ; p>0.1)$, a significant relationship was found for the income tax returns service sub-factor $(\beta=0.126$; $p<0.05)$. Therefore, partial support is found for H3 as only one of the sub-factors of non-routine accounting services sourced by SBOs significantly increased their perceptions of the management benefits received from the SAP.

Hypothesis 4 suggests that there is a positive relationship between the frequency of non-routine accounting services sourced by SBOs and their perceptions of management benefits received from the accounting practitioner. As no significant relationships were found for any of the non-routine services sub-factors (drafting AFS, $\beta=0.065, p>0.1$; IR/ Audit, $\beta=0.029, p>0.1$; income tax returns, $\beta=0.015 p>0.1$ ), $\mathrm{H} 4$ is not supported. Interestingly, despite non-routine services such as drafting AFS and the audit or review of AFS showing positive relationships with compliance benefits, the relationships are not statistically significant in predicting management benefits.

Hypothesise 5 suggests that there is a positive relationship between the frequency of advisory services sourced by SBOs and their perceptions of compliance benefits received from the accounting practitioner. A significant relationship was not found for advisory services and compliance benefits $(\beta=0.006$; $p>0.1$ ). Thus, there is no support for H5. However, tax planning services was significantly positively related to SBOs' perceived 


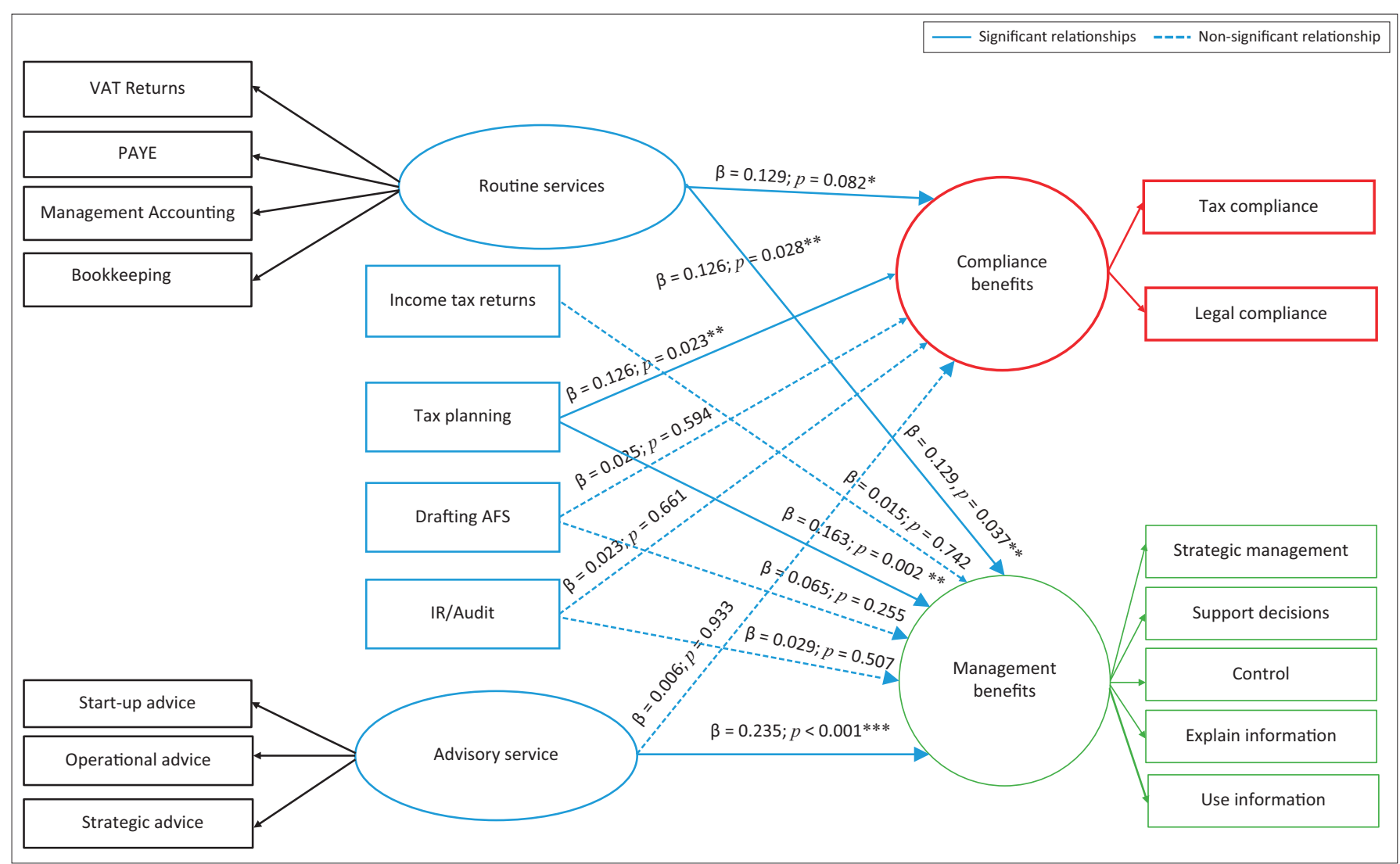

$*, p<0.1$ (two-tailed); **, $p<0.05 ; * * *, p<0.001$.

AFS, annual financial statements; VAT, Value Added Tax; PAYE, Pay-as-you-earn; IR, Independent Review. FIGURE 2: Structural model results.

compliance benefits $(\beta=0.126 ; p<0.05)$, which suggests that this form of advisory service offers a compliance benefit.

Hypothesis 6 suggests that there is a positive relationship between the frequency of advisory services sourced by SBOs and their perceptions of management benefits received from the accounting practitioner. Advisory services $(\beta=0.235$; $p<0.001)$ and tax planning services $(\beta=0.129 ; p<0.05)$ reported are significantly positively related to management benefits. Thus, support is found for H6. Based on the evidence presented, SMEs that more frequently source tax planning services and routine accounting services from their external accounting practitioners experience significantly more compliance and management benefits.

From the comparison of the variance in both compliance and management benefits exhibited by each service, it could be stated that SMEs which regularly source tax planning services perceive the relationship with their external accountant as most beneficial $(\beta=0.142)$, followed by routine accounting services $(\beta=0.129)$ and then by the submission of income tax returns $(\beta=0.126)$ (see Figure 2). As anticipated, tax-related services provide the highest level of compliance benefit, whereas advisory services provide the highest level of management benefits. The perceptions of those SBOs that only source services related to the preparation of AFS or their independent review/audit are that these services offer limited compliance or management benefits.

\section{Discussion}

Literature supports the notion that the frequency by which SMEs source different types of accounting services will affect the benefits of these enterprises obtained from their external accounting practitioners. Accordingly, the regression weights reported, indicating that all types of services have contributed positively towards explaining some degree of the variance in at least one of the potential benefits (management or compliance benefits).

The results further demonstrate that SBOs which source routine accounting services more frequently have a significantly more positive perception about the level of management and compliance benefits they obtain from the relationship with their accounting practitioner than those who use their accounting services less frequently.

As indicated, such services include monthly bookkeeping, management accounting and the filing of Value Added Tax (VAT) returns. It was anticipated that the filing of VAT returns would provide the perception of compliance-related benefits. As bookkeeping is necessary for compiling AFS and management accounts, it was anticipated for this service to provide the impression of compliance and managementrelated benefits.

There is abundant literature on the necessity and management benefits that SMEs could obtain from the use of management 
accounting information (Brijlal, Enow \& Isaacs 2014; Devi \& Samujh 2010; Lavia López \& Hiebl 2015; Marriott \& Marriott 2000; Nandan 2010). Failing to reject the hypotheses that there are significant positive relationships between the frequency by which SMEs source routine accounting services and SBOs' perceptions of both compliance and management benefits obtained was therefore not surprising.

In line with expectations, this article further found that SBOs that frequently source services relating to the filing of income tax returns had a significantly higher perception about the level of compliance benefits obtained from the said relationship. The article also reported a weak negative relationship between SBOs that frequently used their accountants to file income tax returns and their perceptions of management benefits.

To date, there has been an ongoing debate as to whether these types of services provide any form of benefit to SBOs. In most jurisdictions, including South Africa, drafting of the AFS and an independent audit or review of such statements are compulsory, which explains the rate of frequency by which these services are sourced, and compliance benefits are therefore expected. Previous studies have suggested that SMEs could obtain the following benefits from preparing AFs: (1) improved operational control (Burke \& Jarratt 2004; Collis 2012; Schizas et al. 2012), (2) financing benefits (AgyeiMensah 2011; Allee \& Yohn 2009; Amoako 2013; Collis \& Jarvis 2002) and (3) improved operational management (Niemi et al. 2016:169). This article, therefore, hypothesised significant positive relationships between the frequency by which SMEs source services related to the drafting and audit or review of financial statements and their perceptions of both compliance and management benefits received. However, contrary to these hypotheses, no significant relationship was found. Based on the perceptions of SBOs, the article therefore supports the views of scholars such as Halabi et al. (2010), Kirby and King (1997) and Sian and Roberts (2009) that services relating to the preparation and review of AFS offer limited benefit to SMEs beyond that of compliance. Although the South African Companies Act (2008) requires that companies have to submit audited or reviewed AFS to the CIPC, this article suggests that SBOs do not consider the accountants' role in fulfilling this requirement as adding significant compliance benefits. In addition to compliance benefits, literature also suggests that these services could offer management benefits in the form of improved operational control and management and financial benefits. However, this article reported no significant relationships between services relating to the preparation and audit or review of financial statements and management benefits. The researcher would however recommend caution when interpreting these results. The results indicate that whilst SBOs perceive these services to offer limited benefit, it does not suggest that the preparation and audit or review of AFS are not necessary, or that it does not provide any benefit to the SME. What the results do however imply is that SMEs that source services relating just to the preparation and review of AFS from their accountants should not expect to gain benefits relating to enhanced decision-making, operational control or strategic and operational management.

A possible explanation for why SBOs entertain the perception that they gain significant compliance benefits from the filing of income tax returns, but not from the service related to the preparation and review of AFS, may lie in the harsh fines and penalties imposed by the South African Revenue Service (SARS) on individuals and businesses that are found non-tax compliant. In comparison, the implications for those that do not meet the requirements of the Companies Act are limited. This notion was supported by Amoako (2013), who proposed that non-compliance, especially tax compliance, subjects the SBO to severe emotional stress.

The severe impact on SBOs, when their business was not taxcompliant, was also emphasised by Barnardt (2016) and Wolmarans and Meintjes (2015). Niemi et al. (2016), in fact, found that SBOs that regularly source tax-related services from their external accountant were less likely to source voluntary audit services.

In addition, this article also found a significant positive relationship between the frequency by which SMEs source tax planning advice and their perceptions about the level of compliance and management benefits obtained. As such, it is suggested that by sourcing tax-related services (tax returns and tax advisory services) SMEs could gain more compliance and management benefits.

It is broadly accepted that SBOs that regularly source advisory services from their accountants obtain more benefit from the relationship than those who do not have such relationships (Blackburn et al. 2010a; Carey 2015; Devi \& Samujh 2010). The hypotheses tested indicate that there is a significant positive relationship between the frequency by which SMEs source advisory-type services (both general advisory and tax planning) and the perception of the level of management benefits obtained. Despite these perceived benefits, the results of this article reveal that the majority of SMEs (over 50\%) have never used the advisory services offered by a SAP. This may explain why previous studies have reported mixed results regarding the benefits obtained from the relationship with an external accountant. Furthermore, these results suggest that there is much room for more SBOs to make use of advisory services given that most do not use these services despite their substantial management benefits. By seeking external business advice, SBOs have been documented as having enhanced their learning and capabilities for future decision-making (Blomkvist et al. 2016; Sian \& Roberts 2009).

Previous research has also indicated that as a consequence, additional benefits, such as faster adaption to the environment, optimised resource management, growth and, ultimately, better performance, may occur (Carey 2015; Lavia López \& Hiebl 2015). This article empirically supports this work. As expected, results from the empirical tests indicated 
that there is no significant relationship between sourcing advisory services and obtaining compliance benefits. Similarly, there is no significant relationship between sourcing compliance-related services and the perception of management benefits obtained.

\section{Conclusions and contributions}

According to the RBV, accountants, as skilled professionals, are seen to be excellently positioned to assist SMEs in overcoming the constraints resulting from inadequate internal financial management skills. The literature is, however, inconclusive as to whether SBOs do, in fact, perceive the relationship with their external accounting practitioner as beneficial. However, to ensure that SMEs obtain the benefits associated with effective financial management from their accountants, it is necessary for them to source a wide range of services from the external accounting practitioner. The results of this paper demonstrate that various significant relationships exist between the frequency by which SMEs source different types of accounting services and the perception of benefits obtained. The findings present insights into how SMEs could enhance the benefits they get from their external accountant by sourcing certain types of services more frequently. In so doing, this research offers a number of unique contributions of both theoretical and practical significance.

Firstly, from a theoretical perspective, by drawing on the $\mathrm{RBV}$, this article contributes to RBV theory through the lens of SMEs and their financial as well as human capital. Whilst it is evident that resources are fundamental drivers of a business in terms of both performance and competitive advantage (Łobacz \& Głodek 2015), until now it was not clear which of, and how, the various services provided by SAPs contribute from a human capital resources perspective (Han \& Benson 2010). This article demonstrated which of the various services offered by SAPs to SBOs provide benefits from a compliance or management perspective and, as such, which of these services are beneficial from an RBV of the firm.

Secondly, from a practical perspective, by informing SBOs about the types of services they need to source from their accountants to overcome any internal lack of financial and management skills, this article suggests ways for SBOs to secure benefits necessary for the survival and future growth of their businesses. For example, it is recommended that SBOs that lack the required financial management skills to run and grow their businesses should consider sourcing additional services from their SAPs. In particular, the article showed that SMEs that more frequently source routine accounting services (e.g. monthly accounting and bookkeeping) from their SAPs perceived the relationship as not only providing significant compliance benefits, but also significant management benefits. Monthly accounting and bookkeeping services are generally sourced by SMEs that do not employ an internal accountant. It is therefore recommended that owners of start-up businesses that cannot afford the services of a full-time accountant source routine accounting services from an external accountant. This could assist them in overcoming any difficulties associated with the lack of financial management skills. It is, however, suggested that these services are sourced from a competent professional accountant. In terms of tax-related services (tax returns and tax planning services), this article further suggests that SMEs which source such services more frequently could obtain more compliance and management benefits than those that source them less frequently. It is therefore advised that SMEs start by sourcing these services from their accountants.

Finally, the practical implications of the findings of this study are that it is vital to ensure that these skills are transferred from SAPs and their services to the SMEs and SBOs. Furthermore, it is crucial for SMEs to source the right combination of services from their SAPs. Based on the empirical results reported in this article, it is advised that SBOs, specifically those that lack accounting or financial management skills and who are unable to afford the services of a dedicated accountant, outsource their routine accounting tasks to a professional accountant. This article provides evidence supporting the notion that SMEs that regularly source advisory services from their external accounting practitioner obtain greater levels of management benefits. It is therefore recommended that SBOs more frequently use their accountants as a source of business advice. Such advice may be specifically helpful for entrepreneurial ventures when faced with profitability, liquidity, growth or financerelated issues. In addition, from a pedagogical and policy perspective, educators, training providers, banks and business coaches can use these results to encourage SBOs to build a strong relationship with their SAPs and motivate them to source the right combination of services to secure long-term economic sustainability.

\section{Limitations and future research recommendations}

Whilst the findings of this article offer important insights into the value of SAPs in the small business context and from an RBV perspective, there are some limitations that should also be acknowledged. Firstly, a non-probability sampling method was used in this study. Thus, caution should be applied when generalising the results to the entire population of SBOs in South Africa. At the same time, the data are based on a South African sample and, thus, the findings principally apply to South Africa, and similar emerging economy contexts. Thus, there is an opportunity for future research to investigate these relationships in the context of an advanced economy. Secondly, the sample in this study comprised a significant proportion of well-educated (tertiary qualified) SBOs that also had a relatively longer experience as an SBO. Thus, future research could compare more experienced and educated subgroups with less experienced and educated subgroups in terms of their perceived benefits received from the services of a SAP. It is indeed likely that these factors will moderate the relationship. Finally, moderators were not 
included in this study, which are acknowledged as a further limitation. There is a future opportunity to examine other contextual moderators of the relationship, for example, by comparing the results of an advanced economy with that of an emerging economy.

\section{Acknowledgements}

This article is partially based on the first author's (A.O.) thesis, entitled 'Predicting the benefits that small business owners obtain from their accounting practitioners', for the degree of $\mathrm{PhD}$ in Entrepreneurship at the University of Pretoria, South Africa, with supervisor Prof. Jurie J. van Vuuren and co-supervisor Prof. Melodi Botha.

\section{Competing interests}

The authors have declared that no competing interest exists.

\section{Authors' contributions}

All authors contributed equally to this work.

\section{Ethical consideration}

Ethical clearance was obtained from the Research Ethics Committee of the University of Pretoria.

\section{Funding information}

This research received no specific grant from any funding agency in the public, commercial or not-for-profit sectors.

\section{Data availability statement}

Data are available upon request to the corresponding author.

\section{Disclaimer}

The views and opinions expressed in this article are those of the authors and do not necessarily reflect the official policy or position of any affiliated agency of the authors.

\section{References}

Agyei-Mensah, B.K., 2011, 'Financial management practices of small firms in Ghana: An empirical study', African Journal of Business Management 5(10), 3781-3793. https://doi.org/10.5897/AJBM09.285

Allee, K.D. \& Yohn, T.L., 2009, 'The demand for financial statements in an unregulated environment: An examination of the production and use of financial statements by privately held small businesses', The Accounting Review 84(1), 1-25. https:// doi.org/10.2308/accr.2009.84.1.1

Amoako, G.K., 2013, 'Accounting practices of SMEs: A case study of Kumasi Metropolis in Ghana', International Journal of Business and Management 8(24), 73-83. https://doi.org/10.5539/ijbm.v8n24p73

Bagieńska, A., 2016, 'The demand for professional knowledge as a key factor of the development of outsourcing of financial and accounting services in Poland, Business, Management and Education 14(1), 19-33. https://doi.org/10.3846/ bme.2016.313

Barbera, F. \& Hasso, T., 2013, 'Do we need to use an accountant? The sales growth and survival benefits to family SMEs', Family Business Review 26(3), 271-292. https:// doi.org/10.1177/0894486513487198

Barnardt, L., 2016, '10 Steps to engineering financial success', Accountancy SA (June), 32-34.

Beaumont, R., 2012, An introduction to principal component analysis \& factor analysis using SPSS 19, viewed 17 November 2016, from http://www.floppybunny.org/ robin/web/virtualclassroom/stats/statistics2/pca1.pdf.
Bennett, R.J., 2007, 'Expectations-based evaluation of SME advice and consultancy: An example of business link services', Journal of Small Business and Enterprise Development 14(3), 435-457. https://doi.org/10.1108/14626000710773538

Bennett, R.J. \& Robson, P.J.A., 2000, 'SME growth: The relationship with business advice and external collaboration', Small Business Economics 15(3), 193-208, viewed 12 January 2012, from http://www.jstor.org/stable/40229107.

Bennett, R.J. \& Robson, P.J.A., 2010, 'The use of external business advice by SMEs in Britain', Entrepreneurship \& Regional Development: An International Journal 11(2), 37-41. https://doi.org/10.1080/089856299283245

Blackburn, R. \& Jarvis, R., 2010, The role of small and medium practices in providing business support to small- and medium-sized enterprises, viewed 21 August 2015 from http://web.ifac.org/publications/small-and-medium-practices-committee/ information-papers-3\#the-role-of-small-and-mediu.

Blackburn, R., Carey, P. \& Tanewski, G.A., 2010a, Business advice to SMEs: Professional competence, trust and ethics, Certified Accountants Educational Trust, London.

Blackburn, R., Tanewski, G.A. \& Carey, P., 2010b, 'Advice seeking strategies: Entrepreneurs' and accountants' perspectives', in The conference proceedings of the research in entrepreneurship and small business conference, V. 249, Masstricht, Holland, pp. 1-29, viewed 26 July 2016, from https://eprints.kingston. ac.uk/18450/.

Blomkvist, M., Johansson, J. \& Malmström, M., 2016, 'Accounting knowledge in innovative firms - Direct contacts with external auditors for strategic actions', International Journal of Managerial and Financial Accounting 8(3/4), 209-229. https://doi.org/10.1504/IJMFA.2016.10002742

Brijlal, P., Enow, S. \& Isaacs, E.B.H., 2014, 'The use of financial management practices by small, medium and micro enterprises: A perspective from South Africa', Industry and Higher Education 28(5), 341-350. https://doi.org/10.5367/ ihe.2014.0223

Burke, G.I. \& Jarratt, D.G., 2004, 'The influence of information and advice on competitive strategy definition in small- and medium-sized enterprises', Qualitative Market Research: An International Journal 7(2), 126-138. https://doi. org/10.1108/13522750410530039

Burns, J. \& Scapens, R.W., 2000, 'Conceptualizing management accounting change : An institutional framework', Management Accounting Research 11(1), 3-25. https://doi.org/10.1006/mare.1999.0119

Carey, P. \& Tanewski, G., 2016, 'The provision of business advice to SMEs by external accountants', Managerial Auditing Journal 31(3), 290-313. https://doi. org/10.1108/MAJ-12-2014-1131

Carey, P.J., 2008, 'The benefits of services provided by external accountants to small and medium sized enterprises', PhD thesis, University of New South Wales, Sydney.

Carey, P.J., 2015, 'External acocuntants' business advice and SME performance', Pacific Accounting Review 27(2), 166-188. https://doi.org/10.1108/PAR-04-20130020

Ciccotosto, S., Nandan, R. \& Smorfitt, D.B., 2008, 'Issues facing small accounting practices in regional North Queensland: An exploratory study', Australian Accounting Review 18(4), 324-333. https://doi.org/10.1111/j.1835-2561. 2008.0037.x

Collis, J., 2012, 'Determinants of voluntary audit and voluntary full accounts in microand non-micro small companies in the UK', Accounting and Business Research 42(4), 441-468. https://doi.org/10.1080/00014788.2012.667969

Collis, J. \& Jarvis, R., 2000, How owner-managers use accounts, The Institute of Chartered Accountants in England and Whales, London.

Collis, J. \& Jarvis, R., 2002, 'Financial information and the management of small private companies', Journal of Small Business and Enterprise Development 9(2) 100-110. https://doi.org/10.1108/14626000210427357

Davidsson, P., 2004, Researching entrepreneurship, vol. 5, Springer, New York, NY

De Bruyckere, S., Verplancke, F., Everaert, P., Sarens, G. \& Coppens, C., 2018, 'The importance of mutual understanding between external accountants and ownermanagers of SMEs', Australian Accounting Review 1-18. https://doi.org/10.1111/ auar.12251

De Bruyckere, S., Verplancke, F., Everaert, P., Sarens, G. and Coppens, C., 2020, 'The importance of mutual understanding between external accountants and ownermanagers of SMEs', Australian Accounting Review 30(1), 4-21.

Devi, S.S. \& Samujh, H.R,. 2010, Accountants as providers of support and advice to SMEs in Malaysia, The Association of Chartered Certified Accountants, London

Doving, E. \& Gooderham, P.N., 2008, 'Dynamic capabilites as antecedents of scope of related diversification: The case of small firm accountance practices', Strategic Management Journal 841, 12. https://doi.org/10.1002/smj

Dyer, L.M. \& Ross, C.A., 2007, 'Advising the small business client', International Smal Business Journal 25(2), 130-151. https://doi.org/10.1177/0266242607074517

Everaert, P., Sarens, G. \& Rommel, J., 2007, 'Sourcing strategy of Belgian SMEs: Empirical evidence for the accounting services', Production Planning \& Contro 18(8), 716-725. https://doi.org/10.1080/09537280701706195

Everaert, P., Sarens, G. \& Rommel, J., 2010, 'Using transaction cost economics to explain outsourcing of accounting', Small Business Economics 35(1), 93-112. https://doi.org/10.1007/s11187-008-9149-3

Fraser, S., Bhaumik, S.K. \& Wright, M., 2015, 'What do we know about entrepreneurial finance and its relationship with growth?', International Small Business Journal: Researching Entrepreneurship 33(1), 70-88. https://doi.org/10.1177/0266 242614547827

Hair, J.F., Black, W.C., Babin, B.J. \& Anderson, R.E., 2010, Multivariate data analysis: A global perspective, 7th edn., Pearson Education, Inc., Upper Saddle River, NJ. 
Hussain, J., Salia, S. \& Karim, A., 2018, 'Is knowledge that powerful? Financial literacy and access to finance: An analysis of enterprises in the UK', Journal of Small Business and Enterprise Development 25(6), 985-1003. https://doi.org/10.1108/ Business and Enterprise
JSBED-01-2018-0021

Halabi, A.K., Barrett, R. \& Dyt, R., 2010, 'Understanding financial information used to assess small firm performance: An Australian qualitative study', Qualitative Research in Accounting \& Management 7(2), 163-179. https://doi.org/ 10.1108/11766091011050840

Han, L. \& Benson, A., 2010, 'The use and usefulness of financial assistance to UK SMEs', Environment and Planning C: Government and Policy 28(3), 552-566. https://doi.org/10.1068/c0985b

Jones, G. \& Abraham, A., 2007, 'Education implications of the changing role of accountants: Perceptions of practitioners, academics and students educatio implications of the changing role of accountants: Perceptions', in The quantitive analysis of teaching and learning in business, economics and commerce. Forum proceedings, pp. 89-105, University of Melbourne, Melbourne.

Kamyabi, Y. \& Devi, S., 2011, 'Using transaction cost economics and resource-based views in management accounting outsourcing: An empirical study of Iranian SMEs', International Journal of Business and Management 6(3), 87-98. https:// doi.org/10.5539/ijbm.v6n3p81

Kellermanns, F., Walter, J., Crook, T.R., Kemmerer, B. \& Narayanan, V., 2016, 'The resource-based view in entrepreneurship: A content-analytical comparison of researchers' and entrepreneurs' views', Journal of Small Business Management 54(1), 26-48. https://doi.org/10.1111/jsbm.12126

Kirby, D.A. \& King, S.H., 1997, 'Accountants and small firm development: Filling the expectation gap', The Service Industries Journal 17(2), 294-304. https://doi. org/10.1080/02642069700000017

Lavia López, O. \& Hiebl, M.R.W., 2015, 'Management accounting in small and mediumsized enterprises: Current knowledge and avenues for further research', Journal of Management Accounting Research 27(1), 81-119. https://doi.org/10.2308/jmar50915

Łobacz, K. \& Głodek, P., 2015, 'Development of competitive advantage of small innovative firm - How to model business advice influence within the process?', Procedia Economics and Finance 23(October 2014), 487-494. https://doi. org/10.1016/S2212-5671(15)00353-6

Łobacz, K., Głodek, P., Stawasz, E. \& Niedzielski, P., 2016, 'Utilisation of business advice in small innovative firms: The role of trust and tacit knowledge', Entrepreneurial in small innovative firms: The role of trust and tacit knowledge, Entrepreneurial
Business and Economic Review 4(2), 117-138. https://doi.org/10.15678/ Business and ECOno
EBER.2016.040210

Mamabolo, M.A., Kerrin, M. \& Kele, T., 2017, 'Entrepreneurship management skills requirements in an emerging economy: A South African outlook', The Southern African Journal of Entrepreneurship and Small Business Management 9(1), a111. https://doi.org/10.4102/sajesbm.v9i1.111
Marriott, N. \& Marriott, P., 2000, 'Professional accountants and the development of a management accounting service for the small firm: Barriers and possibilities' Management Accounting Research 11(4), 475-492. https://doi.org/10.1006/ mare.2000.0142

McChlery, S., Godfrey, A.D. \& Meechan, L., 2005, 'Barriers and catalysts to sound financial management systems', Journal of Applied Accounting Research 7(iii), 1-26. https://doi.org/10.1108/96754260580001040

Nandan, R., 2010, 'Management accounting needs of SMEs and the role of professional accountants: A renewed research agenda', Journal of Management Accounting Research 8(1), 65-78.

Nawaz, R., 2012, 'The impact of financial information on organizing and managing small business', Published dissertation for the degree Master of Business, Auckland University of Technology, Auckland.

Nieman, G. \& Nieuwenhuizen, C., 2014, Entrepreneurship: A South African perspective, 3rd edn., Van Schaik Publishers, Pretoria.

Niemi, L., Kinnunen, J., Ojala, H. \& Troberg, P., 2016, 'Drivers of voluntary audit in Finland: To be or not to be audited?', Accounting and Business Research 42(2), 169-196. https://doi.org/10.1080/00014788.2012.653742

Oosthuizen, A., 2018, Predicting the benefits that small business owners obtain from their accounting practitioners, University of Pretoria, viewed 17 March 2019, from https://repository.up.ac.za/handle/2263/67864.

Oseifuah, E. \& Manda, D.C., 2017, 'Awareness of state facilitated sources of finance among owners/managers of small and medium enterprises in South Africa', The Journal of Accounting and Managment 7(2), 126-139.

Praulinšs, A. \& Bratka, V., 2014, 'The peculiarities of financial management practices in small businesses', Vadyba 2(25), 97-106.

Sarens, G., Everaert, P., Verplancke, F. \& De Beelde, I., 2015, 'Diversification of external accountants serving small and medium-sized enterprises: Evidence from Belgium', Australian Accounting Review 25(2), 155-174. https://doi.org/10.1111/ auar.12078

Schizas, E., Jarvis, R. \& Daskalakis, N., 2012, SMEs and their advisers: Measuring trust and confidence, London, ACCA.

Sian, S. \& Roberts, C., 2009, 'UK small owner-managed businesses: Accounting and financial reporting needs', Journal of Small Business and Enterprise Development 16(2), 289-305. https://doi.org/10.1108/14626000910956065

Weston, R. \& Gore Jr, P.A., 2006, 'A brief guide to structural equation modeling', The Counseling Psychologist 34(5), 719-751.

Wolmarans, H. \& Meintjes, Q., 2015, 'Financial management practices in successful small and medium enterprises (SMEs)', South African Journal of Entrepreneurship and Small Business Management 7, 88-116. https://doi.org/10.4102/sajesbm. v7i1.8 